\title{
Glutamic Acid Improves Body Weight Gain and Intestinal Morphology of Broiler Chickens Submitted to Heat Stress
}

http://dx.doi.org/10.1590/1516-635x1703355-362

Author(s)
Porto ML'
Givisiez PEN'
Saraiva EP'
Costa FGP'
Moreira Filho ALB"
Andrade MFS"
Brandão PA"I
Guerra RR'v
Iniversidade Federal da Paraíba (UFPB),
Centro de Ciências Agrárias (CCA),
Departamento de Zootecnia, Areia - PB.
"Universidade Federal da Paraíba (UFPB),
Centro de Ciências Agrárias (CCA),
Programa de Pós-Graduação em Zootecnia,
Areia - PB.
"II Universidade Federal de Campina Grande
(UFCG), Centro de Saúde e Tecnologia Rural
(CSTR), Unidade Acadêmica de Medicina
Veterinária - UAMV/Patos - PB.
Iv Universidade Federal da Paraíba (UFPB),
Centro de Ciências Agrárias (CCA),
Departamento de Ciências Veterinárias,
Areia - PB.

\section{-Mail Address}

Corresponding author e-mail address

Patrícia Emília Naves Givisiez

Rodovia PB 079 km 12 - Departamento de Zootecnia - Caixa Postal 13 - PB, Brazil.

Zip code: 58397-000

Phone: 55 (83) 33622300

E-mail: patriciagivisiez@gmail.com

\section{- Keywords}

Amino acid duodenum morphology, environmental temperature, humoral immunity, heat stress, performance.

\section{ABSTRACT}

The objective of this study was to evaluate the effects of $1 \%$ dietary glutamic acid on the body weight, intestinal morphometry, and antiNewcastle antibody titers of broiler chickens submitted to heat stress. One-d-old male broiler chicks ( $n=120)$ were distributed according to a $2 x$ 2 factorial design with two environmental temperatures (thermoneutral or heat stress) and two diets (with 0 or $1 \%$ glutamic acid). Heat stress temperature was constantly maintained $\left(24 \mathrm{~h} /\right.$ day) $5{ }^{\circ} \mathrm{C}$ higher than the thermoneutral temperature. Diets supplied the nutritional requirements of broilers in the pre-starter ( 1 to $7 d$ ) and starter ( 8 to $21 \mathrm{~d}$ ) phases. Birds were vaccinated against Newcastle disease on $d 7$ via eye drop. On days $5,10,15$, and 20, individual body weight was determined, serum samples were collected from five birds, and duodenum samples were collected from four birds per treatment. Serum anti-Newcastle antibody titers were determined by enzyme immunoassay and transformed into $\log _{10}$. Villus height, crypt depth, and villus: crypt ratio were measured in the duodenum. Data were analyzed by ANOVA. Chronic heat stress negatively affected body weight and intestinal morphometry during the pre-starter and starter phases, but had no effect on antibody titers. Dietary glutamic acid supplementation (1\%) improved body weight and intestinal integrity of birds submitted to heat stress when compared with non-supplemented and heat-stressed birds.

\section{INTRODUCTION}

Environmental temperature is an essential factor when aiming at optimizing poultry performance (Furlan et al., 2004). The hypothalamus-pituitary-adrenal axis (HPA) is stimulated in broilers submitted to heat stress, increasing corticosterone levels (QuinteiroFilho et al., 2010). In order to maintain body temperature, energy is used to dissipate heat and therefore, less energy is available for growth. Feed intake is reduced, which negatively affects body weight gain and feed conversion ratio (Furlan et al., 2004; Quinteiro Filho et al., 2010). Hepatic gluconeogenesis is intensified to increase blood glucose levels and, consequently, abdominal fat pad increases (Virden \& Kidd, 2009).

In addition to its metabolic effects, HPA stimulation in heat-stressed birds also causes different degrees of immunosuppression, resulting in atrophy of the thymus, spleen and bursa of Fabricius and accelerating the apoptosis of defense cells (Santin et al., 2003; Quinteiro Filho et al., 2010; Quinteiro Filho et al., 2012). The degree of immunosuppression depends on the duration and intensity of the stress, on broiler genetics, and on the physiology of each individual (Silva et al., 2009).

Changes in dietary ingredients may positively affect the structure and metabolism of the intestinal mucosa, consequently affecting its absorption capacity (Freitas et al., 2001). In this context, dietary 
glutamine and glutamic acid are essential for the maintenance of the mucosa integrity as they are the main energy sources of small-intestine enterocytes ( $\mathrm{Yi}$ et al., 2005).

Glutamic acid is a non-essential amino acid that is transported from the lumen into the enterocyte, where it is transaminated, yielding alpha-ketoglutarate, which enters the citric acid cycle to produce the energy required for cell turnover in the intestine (Burrin \& Stoll, 2009; Blachier et al., 2009). It is also the precursor of other non-essential amino acids, such as arginine, glutamine, and proline (Blachier et al., 2009). Finally, it is involved in the defense mechanisms of the intestinal mucosa by increasing intestinal $\mathrm{pH}$ and the mucous layer thickness (Akiba et al., 2009).

Considering the importance of environmental and nutritional factors during the first weeks of life and the scarcity of studies on the use of glutamic acid as an intestinal trophic agent in poultry, this study evaluated the effects of the dietary addition of $1 \%$ glutamic acid the body weight, intestinal morphometry, and antiNewcastle antibody titers of heat-stressed broiler chicks.

\section{MATERIAL AND METHODS}

All procedures described in the present study were in accordance with the guidelines of the Committee for Animal Use in Research at Universidade Federal da Paraíba (UFPB).

The experiment was carried out with male Cobb 500 broilers $(n=120)$ between one and 21 days of age (d). Chicks were vaccinated against fowl pox, Marek's disease, and infectious bursal disease (IBD) at the hatchery. All birds were vaccinated against Newcastle disease at seven days of age via eye drop (New Vacin, La Sota, Fort Dodge).

Chicks were weighed and distributed according to a completely randomized design into a $2 \times 2$ factorial arrangement with two environmental temperatures (thermoneutral or heat stress) and two diets (containing $0 \%$ (control) or $1 \%$ glutamic acid), resulting in four experimental treatments with 30 birds each: thermoneutral/control, thermoneutral/glutamic acid, heat stress/control, heat stress/glutamic acid.

The birds were allocated to two pens $\left(3 \mathrm{~m}^{2}\right)$ on wood-shavings litter ( $n=30$ chicks per pen) in two different rooms $\left(24 \mathrm{~m}^{2}\right)$ at the Animal Physiology and Molecular Biology laboratory of the Department of Animal Science of the Federal University of Paraíba, Brazil. Water and food were supplied ad libitum, using bell drinkers and plastic pans until 7 days of age and tube feeders thereafter.
Room temperature was maintained at $32^{\circ} \mathrm{C}$ during the first week and decreased $2{ }^{\circ} \mathrm{C}$ per week until reaching $28^{\circ} \mathrm{C}$ in the third week in the thermoneutral treatment. In the heat stress room, temperature was constantly maintained (24 hours per day) $5^{\circ} \mathrm{C}$ higher than the thermoneutral room. Relative humidity was kept at $60 \%$ in both rooms.

Birds were fed a pre-starter (1-7d) and a starter diet (8-21d), containing 2,950 kcal ME/kg diet and $22 \% \mathrm{CP}$ and 3,000 kcal ME/kg diet and $20 \%$ CP, respectively, and were formulated as recommended by Rostagno et al. (2011). Water and feed were provided ad libitum and room temperature and relative humidity were monitored three times daily.

Blood samples were collected on days 5, 10, 15, and 20. All birds were weighed to determine body weight $(\mathrm{g}$ ) before blood collection. Blood samples were collected from five birds per treatment on each day. Anti-Newcastle antibody titers were determined using a commercial enzyme-linked immunosorbent assay (ELISA) (Flock-Check, IDEXX Laboratories, Westbrook, EUA), according to the manufacturer's guidelines. Antibody titers were transformed into $\log _{10}$ before statistical analysis.

Four birds per treatment were sacrificed for duodenal morphometric analyses. The medial region of duodenum was opened with blunt-tip scissors and sections with approximately $5 \mathrm{~cm}$ were stapled onto a cardboard. After rinsing with $0.9 \%$ sterile saline solutions, tissue samples were immersed in Bouin solution for 30 hours before trimming and rinsing with $70 \%$ ethanol. Routine histology processing was carried out and $5-\mu m$ sections were examined. One slide with five to seven tissue sections was mounted per bird and stained with hematoxylin-eosin. Photomicrographs of the duodenal mucosa were taken using a digital camera with 12.1 megapixels (Sony Inc.) connected to a light microscope, with 1.7 optical zoom and 10X-objective. The images were analyzed using Image J software (Abramoff et al., 2004). Villus height and crypt depth of 20 well-oriented villi were measured per bird and villus height:crypt depth ratio (V/C) was calculated. Villus height was measured from the tip of the villus to the villus-crypt junction, whereas crypt depth was defined as the depth of the invagination between adjacent villi. Twenty readings were performed per bird, totaling 80 measurements of each parameter per treatment per bird age.

Body weight, morphometry data, and antibody titers were submitted to analysis of variance (ANOVA) using the statistical software Assistat (UFCG, 2011). Means 
were compared by Tukey's test at 5\% probability level. Body weight and the duodenal villus height and crypt depth of the birds kept under heat stress were also expressed as a percentage relative to thermoneutralcontrol birds, as an average of all ages, in order to assess the possible prevention of the negative effects of heat stress by the dietary addition glutamic acid.

\section{RESULTS}

There was a significant interaction between temperature and diet for body weight on $d 5,10,15$ and 20 (Table 1). Birds fed the control diet and submitted to heat stress were lighter $(p<0.05)$ than those fed the control diet and kept under the thermoneutral environment at all ages. However, when 1\% glutamic acid was added to the diet, both heat-stressed and thermoneutral birds presented similar body weight ( $p>0.05$ ) on $d 5$ and 10. Furthermore, heat-stressed birds fed $1 \%$ glutamic acid were heavier $(p<0.05)$ at all ages compared with the heat-stressed birds fed control diet. The body weight of heat-stressed birds was $72.36 \%$ and $92.48 \%$ relative to that of thermoneutral birds when fed the control diet or $1 \%$ glutamic acid, respectively (average of all ages, data not shown). There was no effect of glutamic acid supplementation on the body weight of thermoneutral birds on d 5, 10, or 20. Nevertheless, on d 15, non-supplemented birds were heavier $(p<0.05)$ compared with supplemented birds.

Body weight gain was lower when birds were submitted to heat stress, but the negative effect was milder when birds were fed glutamic acid in comparison with the birds not supplemented with glutamic acid (Figure 1).

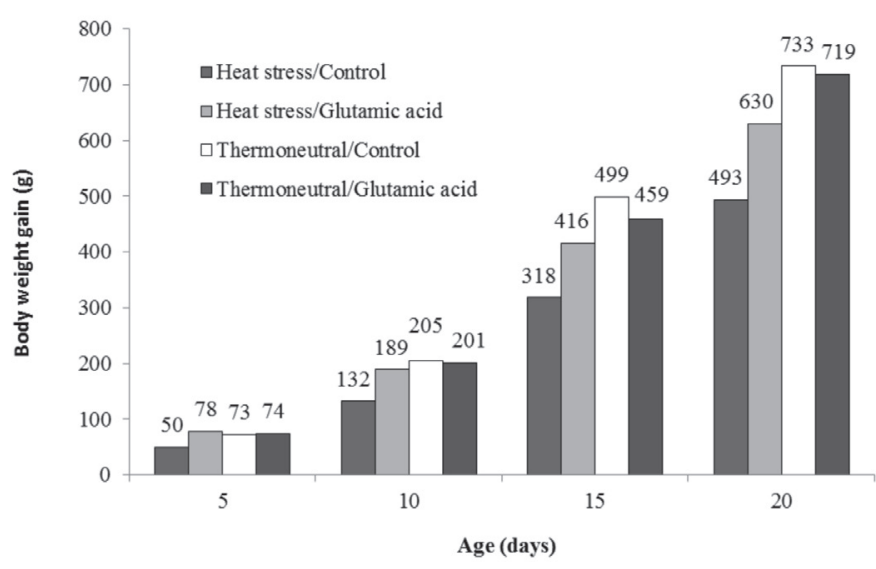

Figure 1 - Body weight gain (g) of broiler chickens at 5, 10, 15 and 20 days of age submitted or not to constant heat stress and fed diets with or without $1 \%$ of glutamic acid.

Environmental temperature and diet showed a significant interaction $(p<0.05)$ for duodenal villus height at all ages (Table 2). Heat stress impaired intestinal mucosa integrity, reducing villus height $(p<0.05)$; however, $1 \%$ glutamic acid supplementation resulted in higher villi $(\mathrm{p}<0.05)$ at all ages. In thermoneutral birds, glutamic acid supplementation promoted an increase in villus height on $\mathrm{d} 5$ and a decrease on $\mathrm{d} 15$ and $d 20(p<0.05)$. Average duodenal villus height of heat-stressed birds was $91.34 \%$ and $99.22 \%$ relative to that of thermoneutral birds when birds were fed the control diet and the diet supplemented with glutamic acid, respectively (data not shown).

Table 1 - Body weight ( $\mathrm{g}$ ) of broiler chickens at 5, 10, 15 and 20 days of age submitted or not to constant heat stress and fed diets with or without $1 \%$ of glutamic acid.

\begin{tabular}{|c|c|c|c|c|}
\hline \multirow{2}{*}{$\begin{array}{l}\text { Body weight }(\mathrm{g}) \\
\text { Treatments }\end{array}$} & \multicolumn{3}{|c|}{ Age (days) } & \multirow[b]{2}{*}{20} \\
\hline & $5^{1}$ & 10 & 15 & \\
\hline Thermoneutral/Control & $121.96 \mathrm{aA}$ & $254.12 \mathrm{aA}$ & $548.22 \mathrm{aA}$ & $782.33 \mathrm{aA}$ \\
\hline Thermoneutral/Glutamic acid & $121.90 \mathrm{aA}$ & $248.66 \mathrm{aA}$ & $505.61 \mathrm{bA}$ & $765.54 \mathrm{aA}$ \\
\hline Heat stress/Control & $98.93 \mathrm{bB}$ & $181.37 \mathrm{bB}$ & $369.61 \mathrm{bB}$ & $543.83 \mathrm{bB}$ \\
\hline Heat stress/Glutamic acid & $127.23 \mathrm{aA}$ & $238.50 \mathrm{aA}$ & $465.44 \mathrm{aB}$ & $679.33 \mathrm{aB}$ \\
\hline \multicolumn{5}{|l|}{ Temperature } \\
\hline Thermoneutral & $121.93 \mathrm{a}$ & $251.39 a$ & $526.91 \mathrm{a}$ & $773.93 \mathrm{a}$ \\
\hline Heat stress & $113.08 \mathrm{~b}$ & $209.93 \mathrm{~b}$ & $417.52 \mathrm{~b}$ & $611.58 \mathrm{~b}$ \\
\hline \multicolumn{5}{|l|}{ Diet } \\
\hline Control ( $0 \%$ glutamic acid) & $110.45 \mathrm{~b}$ & $217.75 \mathrm{~b}$ & 458.91 & $663.08 \mathrm{~b}$ \\
\hline Glutamic acid (1\%) & $124.56 \mathrm{a}$ & $243.58 \mathrm{a}$ & 485.52 & $722.43 \mathrm{a}$ \\
\hline \multicolumn{5}{|l|}{ Probability $^{2}$} \\
\hline Temperature & * & * & * & * \\
\hline Diet & * & * & NS & * \\
\hline Temperature $X$ Diet & * & * & * & * \\
\hline
\end{tabular}

${ }^{1} A-B$ (temperature); a-b (diet) indicate that means in same column are different by Tukey's test $(p<0.05)$

${ }^{2} N S$, not significant; ${ }^{*}, p<0.05$. 
Table 2 - Villus height $(\mu \mathrm{m})$ in the duodenum of broilers at 5, 10,15 and 20 days of age, submitted or not to constant heat stress and supplemented with 0 or $1 \%$ of glutamic acid in the diet.

\begin{tabular}{|c|c|c|c|c|}
\hline \multirow[b]{2}{*}{ Treatments } & \multicolumn{4}{|c|}{ Age (days) } \\
\hline & $5^{1}$ & 10 & 15 & 20 \\
\hline Thermoneutral/Control & $911.20 \mathrm{bA}$ & $1218.31 \mathrm{aA}$ & $1432.91 \mathrm{aA}$ & $1510.53 \mathrm{aA}$ \\
\hline Thermoneutral/Glutamic acid & $914.16 \mathrm{aA}$ & $1229.41 \mathrm{aA}$ & $1389.43 \mathrm{bB}$ & $1477.18 \mathrm{bA}$ \\
\hline Heat stress/Control & $830.70 \mathrm{bB}$ & $1190.83 \mathrm{bB}$ & $1222.54 \mathrm{bB}$ & $1376.76 \mathrm{bB}$ \\
\hline Heat stress/Glutamic acid & $909.55 \mathrm{aB}$ & $1241.97 \mathrm{aA}$ & $1401.60 \mathrm{aA}$ & $1469.55 \mathrm{aB}$ \\
\hline \multicolumn{5}{|l|}{ Temperature } \\
\hline Thermoneutral & $915.09 \mathrm{a}$ & 1223.86 & $1411.17 \mathrm{a}$ & $1493.86 \mathrm{a}$ \\
\hline Heat stress & $870.13 b$ & 1216.40 & $1312.07 \mathrm{~b}$ & $1423.16 \mathrm{~b}$ \\
\hline \multicolumn{5}{|l|}{ Diet } \\
\hline Control (0\% glutamic acid) & $870.86 \mathrm{~b}$ & $1204.57 \mathrm{~b}$ & $1327.73 \mathrm{~b}$ & $1443.65 \mathrm{~b}$ \\
\hline Glutamic acid (1\%) & $914.36 \mathrm{a}$ & $1235.69 a$ & $1395.51 \mathrm{a}$ & $1473.37 \mathrm{a}$ \\
\hline \multicolumn{5}{|l|}{ Probability $^{2}$} \\
\hline Temperature & * & NS & * & * \\
\hline Diet & * & * & * & * \\
\hline Temperature $X$ Diet & * & * & * & * \\
\hline
\end{tabular}

${ }^{1} \mathrm{~A}-\mathrm{B}$ (temperature); $\mathrm{a}-\mathrm{b}$ (diet) indicate that means in same column are different by Tukey's test $(\mathrm{p}<0.05)$

${ }^{2} \mathrm{NS}$, not significant; ${ }^{*}, \mathrm{p}<0.05$.

There was a significant interaction $(\mathrm{p}<0.05)$ between diet and temperature for duodenal crypt depth on days 5,10 , and 20 (Table 3). Only the main factors will be discussed for $d$ 15, because no interactions were detected at this age. Crypt depth was greater $(p<0.05)$ on days 5 and 10 in the heat-stressed birds supplemented with glutamic acid compared with the heat-stressed birds not fed glutamic acid. On $d$ 20 , there was no effect of diet on the crypt depth of heat-stressed birds ( $p>0.05)$. Considering only environmental temperature, heat stress increased crypt depth in supplemented birds $(p<0.05)$ on days 5 and 20, but there was no effect in non-supplemented birds. At 15 days of age, crypt depth was smaller in non-supplemented birds compared with those fed $1 \%$ glutamic acid (82.97 vs. $86.72 \mu \mathrm{m}$, respectively) and in thermoneutral birds compared with heat-stressed birds (83.93 vs. $85.76 \mu \mathrm{m}$, respectively). Crypt depth of heat-stressed birds was $99.50 \%$ and $105.72 \%$ relative to thermoneutral birds, when fed the control diet and $1 \%$ glutamic acid, respectively.

There was a significant interaction $(p<0.05)$ between diet and temperature villus:crypt ratio (V/C) on days 5, 15 , and 20 , but there were no interactions between

Table 3 - Crypt depth $(\mu \mathrm{m})$ in the duodenum of broilers at 5, 10, 15 and 20 days of age submitted or not to constant heat stress and supplemented with 0 or $1 \%$ of glutamic acid in the diet.

\begin{tabular}{|c|c|c|c|c|}
\hline \multirow[b]{2}{*}{ Treatments } & \multicolumn{4}{|c|}{ Age (days) } \\
\hline & $5^{1}$ & 10 & 15 & 20 \\
\hline Thermoneutral/Control & $73.08 \mathrm{bA}$ & $79.01 \mathrm{aA}$ & 81.85 & $87.36 \mathrm{aA}$ \\
\hline Thermoneutral/Glutamic acid & $83.45 \mathrm{aB}$ & $79.49 \mathrm{aA}$ & 86.00 & $71.34 \mathrm{bB}$ \\
\hline Heat stress/Control & $73.34 \mathrm{bA}$ & $74.86 \mathrm{bB}$ & 84.08 & $87.51 \mathrm{aA}$ \\
\hline Heat stress/Glutamic acid & $84.48 \mathrm{aA}$ & $78.80 \mathrm{aA}$ & 87.44 & $87.98 \mathrm{aA}$ \\
\hline \multicolumn{5}{|l|}{ Temperature } \\
\hline Thermoneutral & $78.27 b$ & $79.25 \mathrm{a}$ & $83.93 \mathrm{~b}$ & $79.35 \mathrm{~b}$ \\
\hline Heat stress & $78.91 \mathrm{a}$ & $76.83 \mathrm{~b}$ & $85.76 \mathrm{a}$ & $87.75 \mathrm{a}$ \\
\hline \multicolumn{5}{|l|}{ Diet } \\
\hline Control ( $0 \%$ glutamic acid) & $73.21 \mathrm{~b}$ & $76.93 \mathrm{~b}$ & $82.97 \mathrm{~b}$ & $87.44 \mathrm{a}$ \\
\hline Glutamic acid (1\%) & $83.96 \mathrm{a}$ & $79.15 \mathrm{a}$ & $86.72 \mathrm{a}$ & $79.66 \mathrm{~b}$ \\
\hline \multicolumn{5}{|l|}{ Probability $^{2}$} \\
\hline Temperature & * & * & * & * \\
\hline Diet & * & * & * & * \\
\hline Temperature $\mathrm{X}$ Diet & * & * & NS & * \\
\hline
\end{tabular}

${ }^{1} \mathrm{~A}-\mathrm{B}$ (temperature); $\mathrm{a}-\mathrm{b}$ (diet) indicate that means in same column are different by Tukey's test $(\mathrm{p}<0.05)$

${ }^{2}$ NS, not significant; ${ }^{*}, p<0.05$. 
factors or the main effects of diet and temperature on d10 (Table 4). The V/C ratio decreased $(p<0.05)$ in the duodenum of birds kept under thermoneutrality and supplemented with $1 \%$ of glutamic acid on days 5 and 15. On days 5 and 20 , V/C ratio decreased $(p<0.05)$ in heat-stressed birds independently of diet. Glutamic acid increased $(p<0.05)$ the V/C ratio in the duodenum of birds kept in both environmental temperatures at 20 $\mathrm{d}$ and under heat stress at $15 \mathrm{~d}$.

There was no significant interaction between diet and temperature for anti-Newcastle antibody titers at any ages. Chronic heat stress had no effect on antibody titers ( $p>0.05$ ). On the other hand, the presence of $1 \%$ of glutamic acid in the diet decreased antibody titers only at 15 days of age compared with the control diet ( $2.27 \pm 0.40$ vs $3.01 \pm 0.40, p<0.05)$.

\section{DISCUSSION}

Birds kept under high environmental temperatures need a considerable amount of energy to dissipate heat to maintain homeothermia; however, they also need to reduce their feed intake to minimize the heat increment resulting from feeding. Therefore, there is a decrease in the energy available for physiological processes, including intestinal mucosa turnover and development of fast-growing tissues, such as muscle and bone. The net result is decreased body weight gain and body weight, as reported herein and by other authors (Quinteiro-Filho et al., 2010). It is worth noting that the digestive system is one of the most metabolically active systems in the body, and requires great amounts of energy for the maturation of intestinal cells.

The villus height reduction observed in heat-stressed broilers in the present study corroborates the findings of previous studies (Marchini et al., 2009) and may be related not only to the direct effects of environmental temperature on the mucosa, but also to the indirect effect of reduced feed intake. Feed-restricted or heatstressed birds present shorter villi when compared with birds kept under thermoneutral temperature and nonrestricted birds, indicating that both temperature and the presence of feed in the intestine are determinant factors for mucosa growth (Piva, 2008). Morphology changes due to feed restriction or deprivation include villus adherence, with reduction of their absorptive area, and abnormal crypt formation (Nakage et al., 2007). Marchini et al. (2009) also suggested that the low quantity of food present in the intestinal tract during heat stress impairs its trophic stimulus as well as the secretion of digestive enzymes.

Considering the high rate of intestinal growth and development during the first days of the broilers' life (Uni et al., 1998), and considering that water and feed restriction may delay intestinal mucosa development by several days (Nakage et al., 2007), feed restriction or absence may affect broiler development and growth throughout the production period until market age.

Previous studies suggested that glutamic acid supplementation not only provides energy for the intestine through oxidative metabolism in the enterocytes, but also promotes protein synthesis and reduces the negative impacts of heat stress on

Table 4 - Villus/crypt ratio $(\mu \mathrm{m} / \mu \mathrm{m})$ in the duodenum of broilers at 5, 10, 15 and 20 days of age submitted or not to constant heat stress and supplemented with 0 or $1 \%$ of glutamic acid in the diet.

\begin{tabular}{|c|c|c|c|c|}
\hline \multirow[b]{2}{*}{ Treatments } & \multicolumn{4}{|c|}{ Age (days) } \\
\hline & $5^{1}$ & 10 & 15 & 20 \\
\hline Thermoneutral/Control & $12.47 \mathrm{aA}$ & 15.43 & $17.52 \mathrm{aA}$ & $17.30 \mathrm{bA}$ \\
\hline Thermoneutral/Glutamic acid & $11.01 \mathrm{bA}$ & 15.47 & $16.17 \mathrm{bA}$ & $20.72 \mathrm{aA}$ \\
\hline Heat stress/Control & $11.33 \mathrm{aB}$ & 15.93 & $14.53 \mathrm{bB}$ & $15.74 \mathrm{bB}$ \\
\hline Heat stress/Glutamic acid & $10.76 \mathrm{bB}$ & 16.95 & $16.03 \mathrm{aA}$ & $16.71 \mathrm{aB}$ \\
\hline \multicolumn{5}{|l|}{ Temperature } \\
\hline Thermoneutral & $11.74 \mathrm{a}$ & 15.45 & $16.84 \mathrm{a}$ & $19.01 \mathrm{a}$ \\
\hline Heat stress & $11.05 \mathrm{~b}$ & 16.44 & $15.29 \mathrm{~b}$ & $16.22 \mathrm{~b}$ \\
\hline \multicolumn{5}{|l|}{ Diet } \\
\hline Control (0\% glutamic acid) & $11.90 \mathrm{a}$ & 15.68 & 16.04 & $16.52 \mathrm{a}$ \\
\hline Glutamic acid (1\%) & $10.98 b$ & 16.12 & 16.10 & $18.72 \mathrm{a}$ \\
\hline \multicolumn{5}{|l|}{ Probability $^{2}$} \\
\hline Temperature & * & NS & * & * \\
\hline Diet & * & NS & NS & * \\
\hline Temperature X Diet & * & NS & * & * \\
\hline
\end{tabular}

${ }^{1} A-B$ (temperature); $a-b$ (diet) indicate that means in same column are different by Tukey's test $(p<0.05)$

${ }^{2} \mathrm{NS}$, not significant; ${ }^{*}, \mathrm{p}<0.05$. 
performance because it is a precursor of other amino acids, such as arginine, proline, and glutamine (Reeds et al., 2000). It should be noted that the most of the glutamic acid is metabolized inside the enterocytes after absorption, before entering the bloodstream during the process of transcellular absorption (Blachier et al., 2009). The rapid oxidative metabolism of glutamic acid in the enterocytes supplies sufficient energy for cell proliferation and differentiation and for the recovery of the intestinal mucosa under several stress conditions, as well as stimulates the defense mechanisms of the intestinal mucosa (Akiba et al., 2009; Blachier et al., 2009; Burrin \& Stoll, 2009).

The duodenal morphology results obtained in the present study are consistent with those findings. They indicate that glutamic acid supplementation during the first days of life of heat-stressed broilers minimizes the effects of heat stress and enhances the morphology of the duodenal mucosa, resulting in higher weight gain. Together with crypt depth results, these data suggest that glutamic acid positively affected the mucosa of duodenum, increasing cell proliferation and maintaining villus height. These results also suggest that glutamic acid should be supplemented in prestarter broiler diets, including under thermoneutral conditions, as shown by the higher villi observed. This is probably due to the requirements for the extremely high turnover rate of duodenal enterocytes during the pre-starter phase of birds (Uni et al., 1998).

Deeper crypts are typically observed in situations of high villus turnover, such as rapid growth phases and inflammation (Awad et al., 2009), to maintain the intestinal mucosa integrity, as observed in the present study. However, previous studies demonstrated deeper crypt depth in broilers kept in a thermoneutral environment (Piva, 2008; Marchini et al., 2009) and shallower crypts in piglets fed glutamic acid from 21 to 42 days of age (Silva, 2009).

Both glutamic acid and glutamine are essential for the maintenance of the intestinal mucosa integrity and to support intestinal mucosa growth (Yi et al., 2005). Many studies reported the beneficial effect of glutamine on the intestinal mucosa under several conditions (Sakamoto et al., 2005; Yi et al., 2005). Apparently, glutamic acid is as efficient as glutamine in supporting mucosa growth and protein synthesis in the intestinal mucosa (Blachier et al., 2009); on the other hand, dietary glutamic acid has important functional roles in the intestine that are probably different from those of arterial glutamine (Reeds et al., 2000, Tuhacek et al., 2004).
In weaned piglets, dietary glutamic acid supplementation is important because $70 \%$ of the glutamic acid is metabolized for energy supply to the intestine, thereby maintaining its morphological integrity and health (Burrin \& Stoll, 2009). Pigs fed with glutamic acid from 21 to 42 days of age showed greater villus height and villus:crypt ratio relative to those fed a control diet, suggesting that its supplementation is required especially during the nursery phase (Silva, 2009). In piglets, glutamic acid also prevented jejunum atrophy in the first week after weaning and resulted both in greater villus height in the jejunum 14 days after weaning and greater ability of the small intestine to absorb D-xylose at 7 and 14 days after weaning (Liu et al., 2002). Ebadiasl (2011) observed higher villus height and crypt depth in the jejunum of 35-d-old broilers supplemented with 0.5 and $1 \%$ of glutamine compared with those supplemented similar levels of glutamic acid.

No studies evaluating the effect of glutamic acid on antibody titers of birds were found. In rats, glutamic acid stimulated sodium bicarbonate secretion from the intestinal mucosa to the intestinal lumen and consequently increased intestinal $\mathrm{pH}$ and the thickness of the duodenal mucus, which may contribute to increase intestinal mucosa protection (Akiba et al., 2009).

Glutamic acid can replace glutamine in many metabolic roles, including energy production and amino acid synthesis (Reeds \& Burrin, 2001). However, the energy produced by the oxidative metabolism of glutamic acid does not seem to be used by the cells of the immune system. This occurs possibly because glutamine is greatly used by specific cells from the immune system such as lymphocytes, macrophages, and neutrophils, in addition of being important for lymphocyte proliferation and cytokine production, phagocytosis and secretion in macrophages, as well as bacterial elimination by neutrophils (Newsholme, 2001).

Our results agree with the findings of Santin et al. (2003), who did not observe any decrease in the serum titers of anti-Newcastle and anti-IBD antibodies in heat-stressed broilers after 10 days of age, indicating the importance of factors such as the timing of bird immunization, and the quantity and quality of the antigens used in the vaccines. Accordingly, Silva et al. (2009) reared broilers from 1 to 42 days of age at three environmental temperatures (low, neutral and high) and reported that those maintained at low temperature presented lower antibody titers. Those authors also observed that the titers of heat-stressed 
42- $d$-old broilers were lower compared with the other treatments, probably due to a greater sensitivity to heat at this age. Miranda et al. (2010) found no effect of environmental temperature on anti-Newcastle antibody titers as measured either by ELISA or inhibition of hemagglutination in 10, 21, and 42-d-old broilers.

Although in the present study heat-stress did not affect anti-Newcastle antibody titers, Quinteiro-Filho et al. $(2010 ; 2012)$ reported the activation of the hypothalamus-pituitary-adrenal axis and increased corticosterone levels in heat-stressed broilers, with consequent reduced weight of the lymphoid organs and innate immunity, and simultaneous reduction of BW gain and feed intake. The authors suggested that this neuroimmune dysfunction negatively affects the immune barrier of the intestinal mucosa, allowing bacterial translocation that results in an inflammatory infiltrate, impairing nutrient absorption and body weight gain.

In conclusion, the supplementation of the prestarter and starter broiler diets with $1 \%$ of glutamic acid is effective in minimizing the deleterious effects of chronic heat stress on body weight and in the intestinal mucosa morphology parameters. Heat stress and glutamic acid supplementation had no effect on the serum levels of anti-Newcastle antibodies in prestarter and starter broilers. Studies on the effect of the interaction of heat stress with glutamic acid and/or glutamine on the local immune response in broilers, including evaluation of mucus thickness, goblet cell counts, and determination of immunoglobulin A levels in the intestinal mucosa, in addition of the evaluation of the presence of inflammatory infiltrate, should provide interesting and new insights on the importance of these amino acids for intestinal integrity and morphophysiology.

\section{ACKNOWLEDGEMENTS}

The authors thank CNPq for the scholarship granted to M.L. Porto and Guaraves Alimentos Ltda. for donating the one-day-old chicks.

\section{REFERENCES}

Abramoff MD, Magalhaes PJ, Ram SJ. Image processing with image J. Biophotonics International 2004;11(7):36-42.

Akiba Y, Kaunitz JD. Luminal chemosensing and upper gastrointestinal mucosal defenses. American Journal of Clinical Nutrition 2009;90(3):826S-831S.

Awad Wa, Ghareeb K, Abdel-Raheem S, Böhm J. Effects of dietary inclusion of probiotic and synbiotic on growth performance, organ weights, and intestinal histomorphology of broiler chickens. Poultry Science 2009;88(1):49-56.

Blachier F, Boutry C, Bos C, Tomé D. Metabolism and functions of L-glutamate in the epithelial cells of the small and large intestines. American Journal of Clinical Nutrition 2009;1:814-821.

Burrin DG, Stoll B. Metabolic fate and function of dietary glutamate in the gut. American Journal of Clinical Nutrition 2009;1:850-856.

Ebadiasl G. Effects of supplemental glutamine and glutamate on growth performance, gastrointestinal development, jejunum morphology and Clostridium perfringens count in ceacum of broilers. Epsilon 2011;331: 41

Freitas BCF, Baião NC, Nunes IJ. Fisiologia digestiva do frango de corte nos primeiros dias de vida: digestão da gordura. Caderno Técnico de Veterinária e Zootecnia 2001;34:7-13.

Furlan RL, Macari M, Luquetti BC. Como avaliar os efeitos do uso de prebióticos, probióticos e flora de exclusão competitiva. $5^{\circ}$ Simpósio Técnico de Incubação, Matrizes de Corte e Nutrição; 2004; Balneário Camboriú, Santa Catarina. Brasil.

Liu TP, Jian YZ, Xiong SQ, Zhou XH, Cheng. Effects of dietary glutamine and glutamate supplementation on small intestinal structure, active absorption and DNA, RNA concentration in skeletal muscle tissue of weaned piglets during d 28 to 42 of age. Asian-Australasian Journal of Animal Sciences 2002;15(2):238-242

Marchini CFP, Silva MRBM, Nascimento ME, Beletti ME, GUMARÃES EC, SOARES HL. Morfometria da mucosa duodenal em frangos de corte submetidos a temperatura ambiente cíclica elevada. Arquivo Brasileiro Medicina Veterinária e Zootecnia 2009;61(2):491-497

Miranda CC, Sartori JR, Fascina VB, Pezzato AC, Castelo PG, Carvalho FB. Efeito de fontes de minerais orgânicos e inorgânicos e de temperatura ambiente no sistema de frangos de corte. Conferência FACTA 2010 de Ciência e tecnologia Avícolas; 2010; Santos, São Paulo. Brasil.

Nakage ES, Pires DL, Morita VS, Boleli IC. Pintos de corte respondem ao jejum pós-eclosão com aumento da proteção do epitélio intestinal. Revista Brasileira de Ciência Avícola 2007;9 Supl 8:12.

Newsholme P. Why is L-glutamine metabolism important to cells of the immune system in health, post injury, surgery or infection? Journal Nutrition 2001;131:2515-2522

Piva $\mathrm{AH}$. Efeito da forma física da ração para frangos de corte criados em diferentes temperaturas [dissertação]. Jaboticabal (SP): Univerisidade Estadual Paulista; 2008

Quinteiro-Filho WM, Ribeiro A, Ferraz-De-Paula V, Pinheiro PL, Sakai M, Sá LRM, Ferreira AJP, Palermo-Neto, J. Heat stress impairs performance parameters, induces intestinal injury, and decreases macrophage activity in broiler chickens. Poultry Science 2010;89:1905-1914.

Quinteiro-Filho WM, Rodrigues $\mathrm{V}$, Ribeiro A, Ferraz-De-Paula $\mathrm{V}$, Pinheiro PL, Sá LRM, Ferreira AJP, Palermo-Neto, J. Acute heat stress impairs performance parameters and induces mild intestinal enteritis in broiler chickens: Role of acute hypothalamic-pituitary-adrenal axis activation. Journal of Animal Science 2012;90(6):1986-1994

Reeds PJ, Burrin DG, Stoll B, Jahoor F. Intestinal glutamate metabolism. Journal of Nutrition 2000;130:978-982.

Reeds PJ, Burrin DG. Glutamine and the bowel. Journal of Nutrition $2001 ; 131: 2505-2508$

Rostagno HS. Tabelas brasileiras para aves e suínos. Composição de alimentos e exigências nutricionais. $2^{\mathrm{a}}$ ed. Viçosa: Universidade Federal de Viçosa; 2011 
Sakamoto MJ. Influência da glutamina e vitamina E sobre o desempenho resposta imunológica e morfometria intestinal em frango de corte [dissertação]. Maringá (PA): Universidade Estadual de Maringá; 2005.

Santin E, Maiorka A, Polveiro WJC, Paulillo AC, Laurentiz AC, Borges AS, Fischer da Silva AV. Effect of environmental temperature on immune response of broilers. Journal of Applied Poultry Research 2003;12:247250.

Silva CC. Avaliação do uso de leveduras (Saccharomyces cerevisiae) inativas e hidrolizadas nas dietas iniciais de leitões [dissertação]. Pirassununga (SP): Universidade de São Paulo; 2009.

Silva VK, Della Torre Da Silva J, Torres KAA, Faria Filho DE, Hirota Hada F, Barbosa De Moraes VM. Humoral immune response of broilers fed diets containing yeast extract and prebiotics in the prestarter phase and raised at different temperatures. Journal of Applied Poultry Research 2009;18:530-540.
Tuhacek LM, Mackey AD, Li N, Demarco VG, Stevens G, Neu J. Substitutes for glutamine in proliferation of rat intestinal epithelial cells. Nutrition 2004;20:292-297

Uni Z, Ganot S, Sklan D. Posthatch development of mucosal function in the broiler small intestine. Poultry Science 1998;77:75-82.

Universidade Federal de Campina Grande. Assistat versão 7.6 beta. Campina Grande; 2011

Virden WS, Kidd MT. Physiological stress in broiler: Ramifications on nutrient digestibility and responses. Journal of Applied Poultry Research 2009:18:338-347

Yi GF, Allee GL, Knight CD. Impact of glutamine and oasis hatchling supplement on growth performance, small intestinal morphology and immune response of broilers vaccinated and challenge with Eimeria maxima. Poultry Science 2005;84:283-293. 